\title{
Impact of an intrusion by the Northern Current on the biogeochemistry in the eastern Gulf of Lion, NW Mediterranean
}

\author{
Ross Oliver N. ${ }^{1,{ }^{*}}$, Fraysse Marion ${ }^{1,2}$, Pinazo Christel ${ }^{1}$, Pairaud Ivane ${ }^{2}$
}

\begin{abstract}
${ }^{1}$ Aix-Marseille University, CNRS, University of Toulon, IRD, MIO UM 110, 13288, Marseille, France
${ }^{2}$ Institut Français de Recherche pour l'Exploitation de la Mer, Laboratoire Environnement Ressources Provence Azur Corse, F-83507 La Seyne sur Mer, France
\end{abstract}

*Corresponding author : Oliver N. Ross, email address : oliver.ross@univ-amu.fr

\begin{abstract}
:
We present the results from the RHOMA2011-LEG2 campaign that took place in the eastern Gulf of Lion from 7 to 17 Oct 2011 and combine them with remote sensing observations and results from a 3D coupled hydrodynamic-biogeochemical model to study an intrusion event of the Northern Current (NC) onto the continental shelf in the Gulf of Lion (NW Mediterranean). Our analysis shows that during the intrusion, the previously upwelled nutrient-rich water present on the shelf is replaced by warmer and mostly oligotrophic NC water within a matter of 2-3 days. This has a marked impact on the local biogeochemistry in the Gulf with pre-intrusion Chl-a concentrations in the surface layer of over $0.5 \mathrm{mg}$ m-3 dropping to near the detection limit within less than $72 \mathrm{~h}$. The intrusion event leads to a dramatic albeit short-lived regime shift in the limiting nutrient for primary production: prior to the intrusion most of production on the shelf is nitrogen limited while the intrusion induces a shift to phosphorous limitation. The relatively high frequency of occurrence of these intrusions in combination with their impact on the local ecosystem make them primary targets for future study.
\end{abstract}

\section{Highlights}

An Intrusion event of the Northern Current was observed and modelled in the Gulf of Lion. Intrusions can completely flush the eastern Gulf of Lion within 2-3 days. Intrusions can produce dramatic shot-lived regime shifts in the local biogeochemistry.

Keywords : Northern Current, Gulf of Lion, Intrusion, Continental shelf, Biogeochemical modelling, Regime shift 

typical system for studying river/shelf/open sea interactions. Due to the Rhone River and frequent upwelling events, the GoL is one of the most productive areas in a mostly oligotrophic Mediterranean Sea [de Madron et al., 2011].

(NC, Figure 1a), a slope current that passes along the continental slope off the GoL, where it

bounds and controls shelf circulation, effectively separating the typically nutrient rich shelf

from the oligotrophic open Mediterranean. It originates from the confluence of the Eastern

and Western Corsican Currents and flows from the Ligurian to the Balearic Sea forming part

of the general cyclonic circulation in the Western Mediterranean.

The NC exhibits a seasonally variable flux (maximal in winter) between $1-2 \mathrm{~Sv}$ which is comparable to the fluxes through the Strait of Gibraltar [Alberola et al., 1995]. The NC is wider and shallower in summer (50km and $250 \mathrm{~m}$ respectively) when it flows further off-

(a)

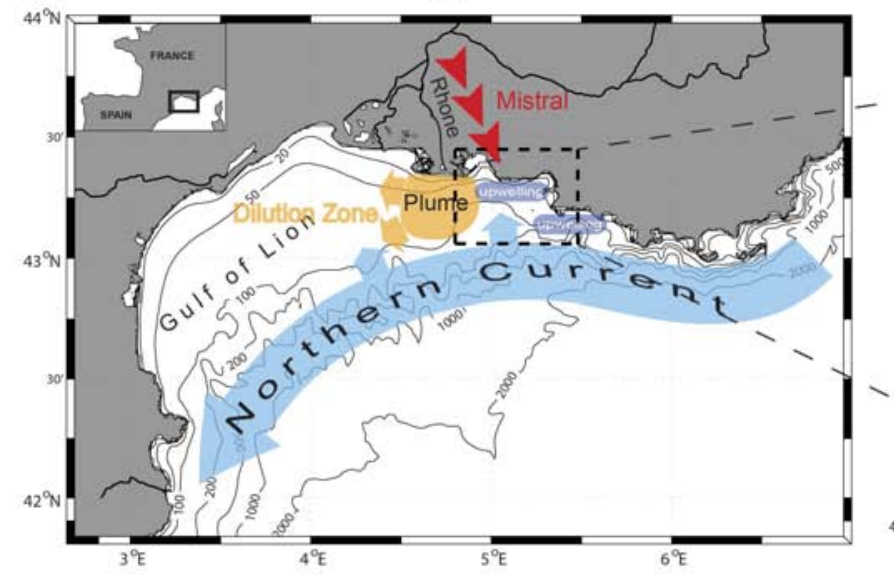

(b)

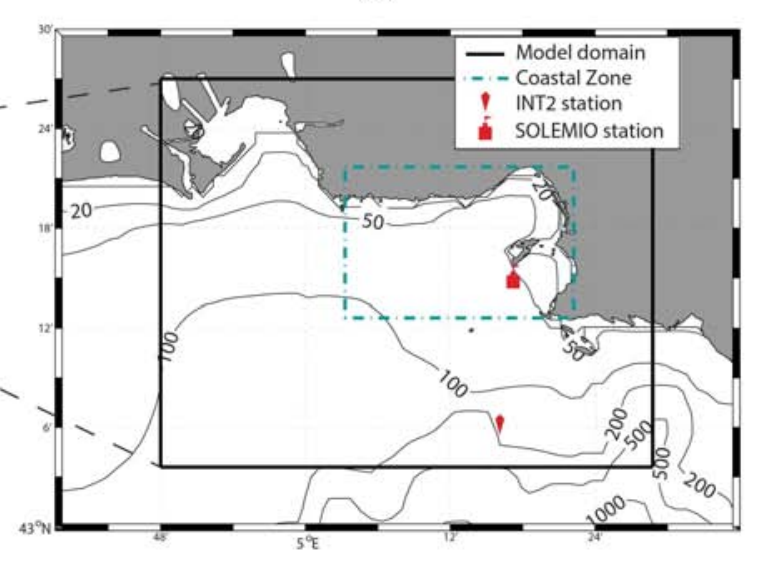

Figure 1: (a) Map of the Gulf of Lion showing the location of the study area at the eastern entrance (dashed box) and the dominant hydrodynamic and meteorological features, including the Northern Current and its northward intrusions onto the shelf. (b) Zoom of the study area, showing the location of the coastal zone budget box and the INT2 and SOLEMIO observational stations. 

can penetrate onto the GoL shelf [Millot, 1999; Petrenko, 2003; Rubio et al., 2009]. frequently, they tend to occur at the eastern entrance to the Gulf [Petrenko et al., 2005] and at the center [Estournel et al., 2003], with more rare occurrences at the south-western side [Petrenko et al., 2008]. Using data from 12 coastal cruises, Gatti et al. [Intrusions of the

Mediterranean Northern Current on the eastern side of the Gulf of Lion's continental shelf: characterization and generating processes, submitted to Journal of Geophysical Research 2015] found that intrusions can occur during any season of the year and that the intrusion flux can amount to $0.37 \mathrm{SV}$ or $30 \%$ of the flux of the NC itself. They also carried out numerical realistic simulations which suggest that intrusions can occur as often as three to four times per month with durations of a few days to two weeks. By combining in situ observations and high-resolution modelling, Barrier et al. [2015] observed a total of 12 intrusion events during easterly winds [Petrenko, 2003; Petrenko et al., 2013]. NC intrusions onto the shelf have also been linked to the strength of density stratification and the pycnocline depth with the NC splitting into a main and a northern branch, the latter creating an intrusion if the stratification is strong and shallow [Echevin et al., 2003; Petrenko et al., 2005]. However, other studies showed that intrusions at the eastern entrance to the GoL could occur independently of stratification [Petrenko, 2003]. These seemingly contradicting results suggest that the real causes of intrusions are still unclear [Petrenko et al., 2005] although the shift in the local wind regime may play a crucial role [Pairaud et al., 2011; Petrenko et al., 2008]. Barrier et 
91

easterly or north-westerly wind events and they found them to be most frequent in the autumn and winter months.

While the Northern Current (NC) and its intrusions onto the continental shelf in the

Gulf of Lion have been widely studied from a hydrodynamical point of view [Alberola and Millot, 2003; Petrenko, 2003], including intrusions in the eastern GoL [Pairaud et al., 2011; Petrenko et al., 2008], little is known about the impact of these intrusions on the biogeochemistry. The biogeochemical functioning of the eastern GoL is complex and largely driven by the interplay of Rhone River run-off, hydrodynamics, and air-sea interactions. The Rhone River is the most significant source of freshwater and nutrients to the Mediterranean

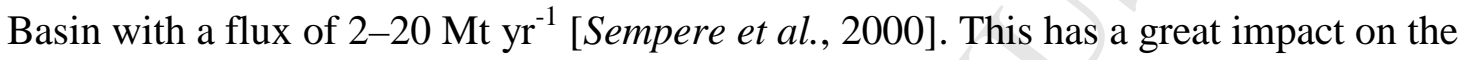
biogeochemical functioning of the GoL and directly affects primary production: about $50 \%$ of the annual primary production in the GoL can be attributed to terrigenous inputs [Coste, 1974; Morel et al., 1990]. Typically the Rhone River Plume extends westward but eastward intrusions of plume water into the Bay of Marseille (inside our study area) have also been observed [Fraysse et al., 2014; Gatti et al., 2006]. The variability in the Rhone River run-off also has a measurable impact on the fisheries industry. In a study covering a nearly 30 -year period from 1973-2000, a correlation was found between the interannual variability of the Rhone River run-off and the landings of Common Sole (Solea solea) 5 years later, particularly in the eastern GoL port of Martigues where about 50\% of landings for the GoL are recorded (M. Harmelin, pers. comm.).

In addition, two dominant winds act as important forcing components: (i) northwesterlies (Mistral in Figure 1), which favour upwelling [Millot, 1990], and (ii) southeasterly winds, which favour downwelling [Fraysse et al., 2014; Pairaud et al., 2011].

During an upwelling event, cold, nutrient-rich waters are brought up to the euphotic zone $[E l$ Sayed et al., 1994], which can lead to an increase in primary production. 
117 GoL shelf area, just after an upwelling event, focussing primarily on the effect on the local

118 biogeochemistry. This is achieved through combining results from a 3D coupled

hydrodynamical-biogeochemical model of the region with in situ (nutrients, chl, current

velocities) and remote sensing observations (SST, Ocean colour). The analysis shows that NC

intrusions can have a significant impact on the shelf biogeochemistry and bring about a

dramatic regime shift in the local ecosystem within a rather short period of time that lasts for the duration of the intrusion event.

\section{Materials and Methods}

\subsection{Field sampling and remote sensing data}

All observational in situ data collected between 7 to 17 October 2011 stems from the

RHOMA2011-LEG2 campaign that took place in the eastern Gulf of Lion (Figure 1). The in situ data was collected aboard RV Tethys II using an SBE19PlusV2 CTD that was also equipped with an optical backscatter sensor (Campbell Scientific OBS3+) and a fluorimeter (WetLabs WetStar). In addition, discrete water samples were collected at various depths for nutrient analysis and for calibration of the fluorescence data [see Materials and Methods in Fraysse et al., 2013 for details on in situ data collection and processing]. The current velocities and directions were obtained from the $150 \mathrm{kHz}$ hull-mounted Acoustic Doppler Current Profiler (ADCP) of the RV Tethys II. Currents were recorded along the vessel's track over the course of several hours each day. ADCP data for 18 October 2011 stems from the SPECIMED campaign that took place every month between 2010 and 2014, and was collected with a $300 \mathrm{kHz}$ ADCP mounted on a towed fish that was suspended from the vessel's side at a depth of between 1-2m. 
142 EUR_L3S_NRT_OBSERVATIONS_010_009_a). These data come at a horizontal resolution

143 of $0.02^{\circ}$ and are typically collected at night to reduce potential errors due to the skin effect. In

144 an attempt to further control the skin effect we used mooring data from the "Le Planier"

145 mooring at $\left(43.21^{\circ} \mathrm{N}, 5.23^{\circ} \mathrm{E}\right)$ to calibrate the satellite SST. The average offset between the

146 mooring and the satellite derived SST during our period of study was $+1{ }^{\circ} \mathrm{C}$ which suggested

147 that some skin effect remained which we subtracted from the satellite data. Each SST pixel

148 represents the daily mean collected from various sensors. One single snapshot thus represents

149 a collage of values collected over a range of up to $12 \mathrm{~h}$.

150 The ocean colour data originated from the MODIS platform and were processed using 151 the OC5 algorithm [Gohin et al., 2005] to obtain chlorophyll- $a$ concentrations (Chl- $a$ ). The

152 horizontal resolution is about $1.1 \mathrm{~km}$ and due to the OC5 algorithm they have a lower 153 detection threshold for Chl- $a$ of $0.1 \mathrm{mg} \mathrm{m}^{-3}$.

\subsection{The model}

The hydrodynamic model MARS3D [Lazure and Dumas, 2008] was used in the

RHOMA configuration [Pairaud et al., 2011] coupled to the ECO3M biogeochemical platform [Baklouti et al., 2006a; Baklouti et al., 2006b] in the MASSILIA-P configuration

[Fraysse et al., 2014; Fraysse et al., 2013]. The model structure is primarily based on the pelagic plankton ecosystem model that was published previously [Faure et al., 2010a; Faure et al., 2010b; Pinazo et al., 1996]. It contains 5 compartments (phytoplankton, heterotrophic bacteria, dissolved and particulate organic matter and dissolved inorganic matter) and allows for a variable intracellular content of carbon, nitrogen and phosphorous in the phytoplankton and bacteria groups. The physical-biogeochemical coupled model was applied to the eastern GoL at a horizontal resolution of $400 \mathrm{~m}$ using 30 vertical sigma levels. The model run covered the years 2007-2011 and is in its setup (spin-up, boundary conditions, parameter 
167 Methods]. The values for the biogeochemical parameters at the open boundary were chosen

168 based on a sensitivity analysis with difference OBCs to deliver results that were in best

169 quantitative agreement with observations at the fixed stations within the model domain

170 (where nutrient samples were taken) and also with observations from remote sensing chl data.

171 Two different approaches were used for comparing the model results to observations

172 of velocities and temperature. For the quantitative comparison of the model with ADCP

173 velocities, we used a model output every 10 minutes such that the error in synopticity is no

174 larger than +/- 5 minutes. When comparing the model SST with the satellite image, we used

175 the collection time of each pixel in an image to obtain the mean time and chose the closest

176 model time step for the comparison.

177 The same applies for the comparison of the MODIS image with the model surface

178 concentrations of Chl- $a$. In order to provide a fair visual comparison between the model data

179 and satellite images, all model values of Chl- $a$ less than the OC5 algorithm's detection limit

180 have been set to $0.1 \mathrm{mg} \mathrm{m}^{-3}$.

For all satellite/model comparisons, the satellite data was interpolated onto a

182 horizontal $400 \times 400 \mathrm{~m}$ grid to match the model resolution. The mass budgets were calculated,

183 based on equations 3 and 4 from [Fraysse et al., 2014].

\section{Results}

The wind pattern during the study period is characterized by a 1-week period of strong Mistral winds that lasted from about 7-13 October 2011, followed by two days of strong easterlies (Figure 2). The Mistral caused a persistent upwelling event along the coast, the last stages of which are still visible on the SST snapshot from 13 October (Figure 3a, b) where the upwelled water can be identified from the relatively cold water all along the coast. 


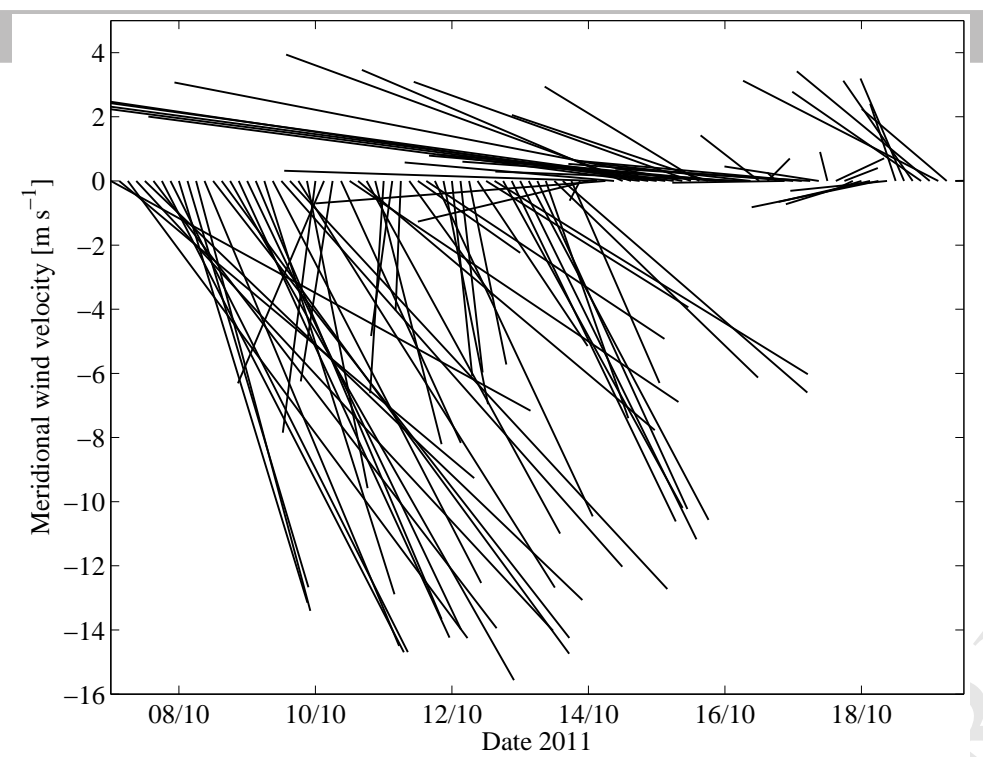

Figure 2: MM5 (5th generation PSU/NCAR mesoscale) model wind vectors near the SOLEMIO station (at $43.25^{\circ} \mathrm{N}, 5.27^{\circ} \mathrm{E}$ ). Visible is the strong Mistral event from the $7^{\text {th }}$ till the $13^{\text {th }}$, followed by a short period of strong easterlies and relative calm from the $17^{\text {th }}$ onward.

This upwelling event brought higher concentrations of nutrients to the surface layer and created a short-lived bloom (see Fraysse [2014] for details). In comparison to the SST estimates from satellites, the model captures both the magnitude and location of the upwelling event quite well.

At the same time, the Northern Current (NC) is present with maximal velocities of over $0.5 \mathrm{~m} \mathrm{~s}^{-1}$ and it begins to intrude onto the continental shelf in the eastern Gulf of Lion (Figure 3). The intrusion starts on 13 October 2011 and is characterized by the emergence of a strong shoreward component of the velocity vectors which is visible in both the model simulations and in situ observations (Figure 3a).

On 16 October 2011 , both the velocity and temperature images show that the cooler onshore water that was present only three days earlier has now been replaced with warmer water from the NC (Figure 3c-d). The intrusions of the warmer NC water led to a rise in the surface water temperature on the shelf of up to $4^{\circ} \mathrm{C}$. The onshore velocity vectors reach values of over $0.6 \mathrm{~m} \mathrm{~s}^{-1}$ and the location of the velocity maximum has moved slightly westward. We begin to see the development of an anticyclonic eddy, the so-called Marseille Eddy [Schaeffer et al., 2011]. Vertical velocity profiles confirm that the intrusion is not only limited to the surface layer but extends to depths of at least $70 \mathrm{~m}$ as we have significant on- 
208 and modelled velocities, we find that the model tends to generally overestimate in situ

209 velocities on the shelf (Figure 3f), while underestimating the velocities further offshore (the

210 mean weighted difference over all depths and locations is $0.014 \mathrm{~m} \mathrm{~s}^{-1}$ with an RMSE of $0.1 \mathrm{~m}$

(a) 13 Oct $2011 \mathrm{SST}$ and velocities at $18.5 \mathrm{~m}$

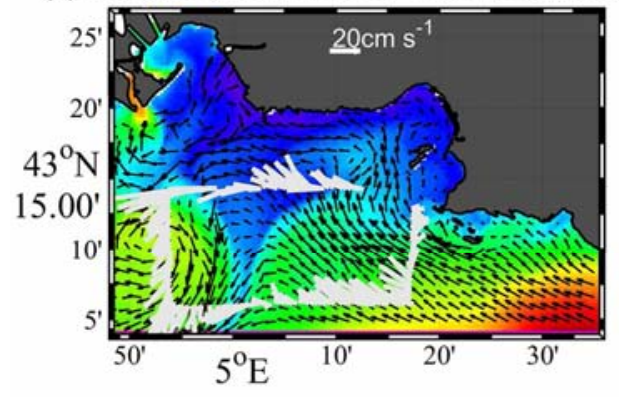

(c) 16 Oct $2011 \mathrm{SST}$ and velocities at $18.5 \mathrm{~m}$

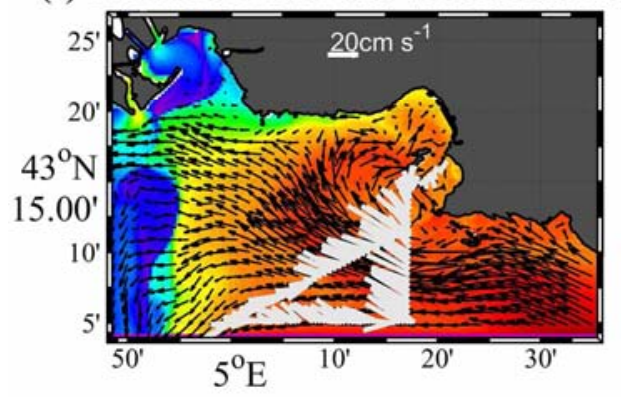

(e) 16 Oct $2011 \mathrm{~T} /$ velocities at $66.5 \mathrm{~m}$

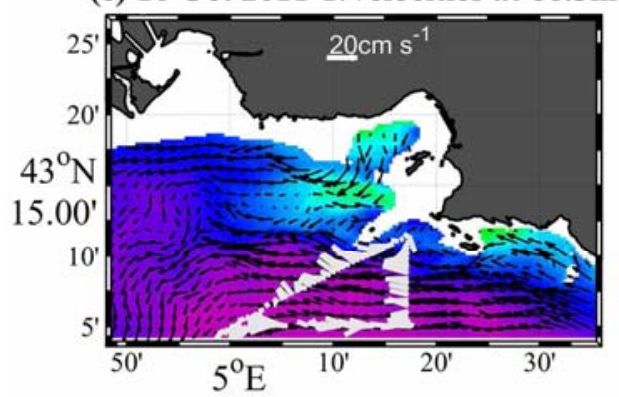

(g) 18 Oct $2011 \mathrm{SST}$ and velocities at $44.9 \mathrm{~m}$

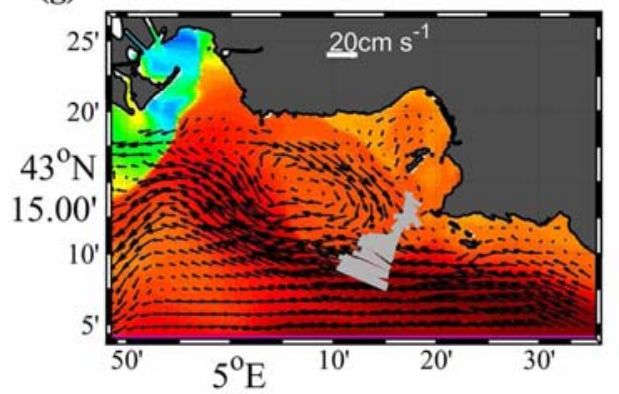

(b) SST on 13-Oct-2011 (56\%)

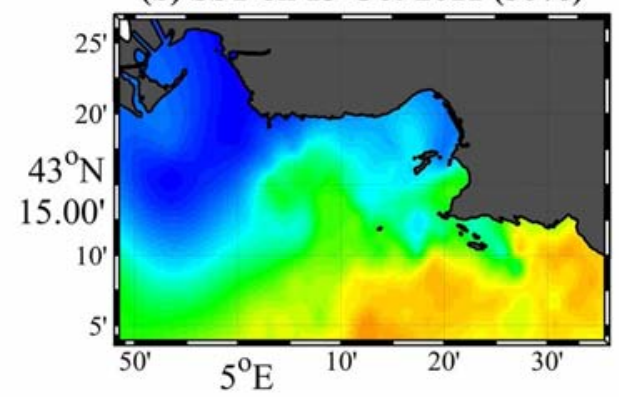

(d) SST on 16-Oct-2011 (83\%)

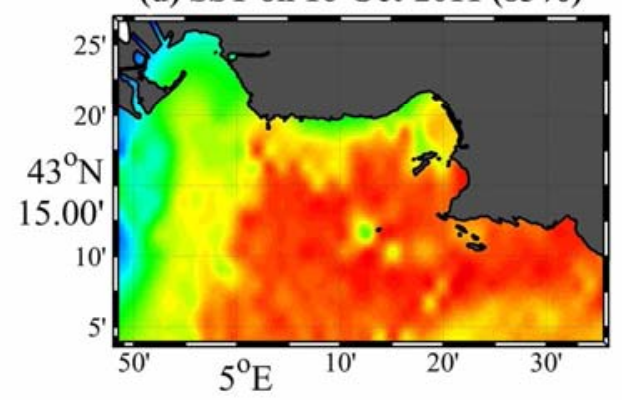

(f) 16 Oct 2011 velocities at $18.5 \mathrm{~m}$

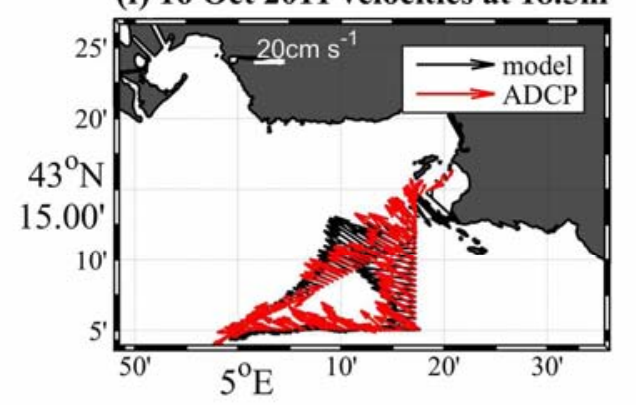

17

(h) SST on 18-Oct-2011 $(90 \%)$

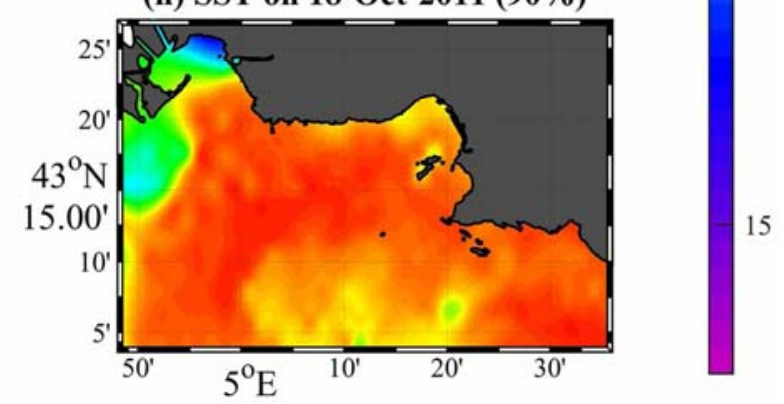

Figure 3: (a) Model velocities (black arrows) with measured ADCP velocities (light grey bars) at a depth of $18.5 \mathrm{~m}$ on 13 Oct 2011 superimposed on modelled SST. (b) Remotely sensed SST for 13 Oct 2011 (the percentage in brackets gives the satellite coverage for that day). Corresponding plots for (c-d) 16 Oct 2011 and (g-h) 18 Oct 2011. (e) as in (c) but with both the temperature and velocities at $66.5 \mathrm{~m}$. (f) Comparing modelled with measured velocities along the ship track at $18.5 \mathrm{~m}$ depth. The color scale is in ${ }^{\circ} \mathrm{C}$. 
212 in the south-eastern part of the model domain was also observed during the event of October

2132007 described by Pairaud et al. [2011]. Nevertheless, the predominant north-westward

214 current direction is generally well reproduced by the model, except at the southern boundary.

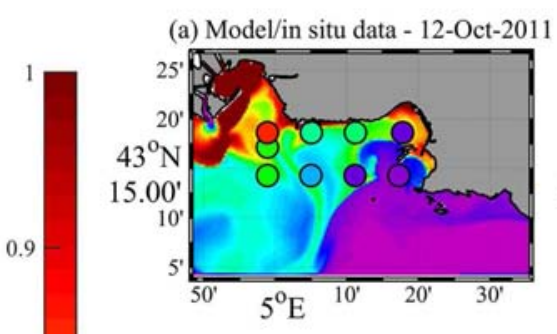

(c) Model/in situ data - 13-Oct-2011

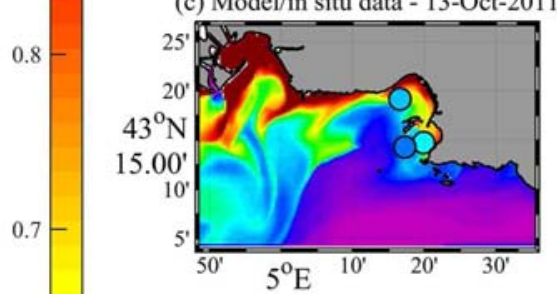

(e) Model/in situ data - 14-Oct-2011

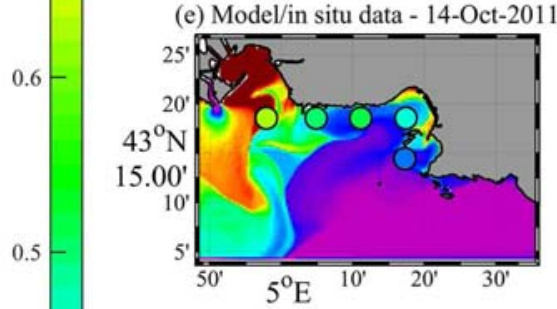

(g) Model/in situ data - 15-Oct-2011

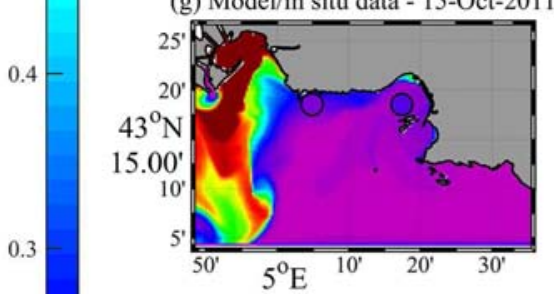

(i) Model/in situ data - 16-Oct-2011

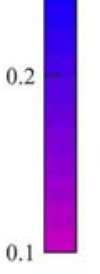

(b) MODIS OC5 12-Oct-2011

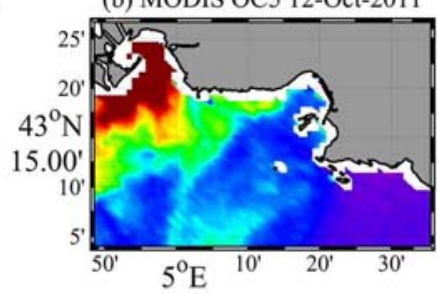

(d) MODIS OC5 13-Oct-2011

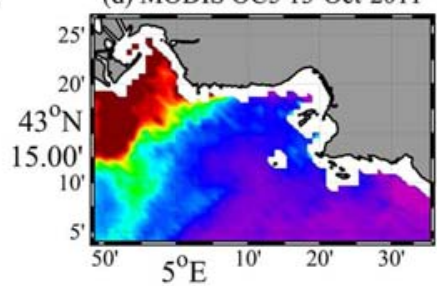

(f) MODIS OC5 14-Oct-2011

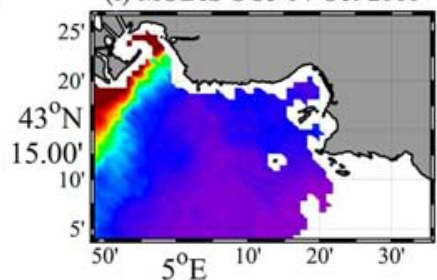

(h) MODIS OC5 15-Oct-2011

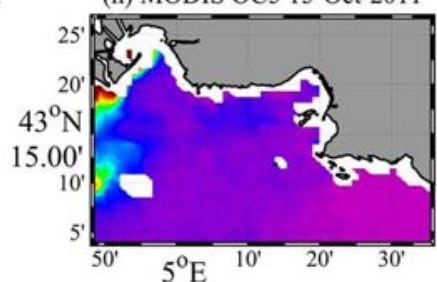

(j) MODIS OC5 16-Oct-2011

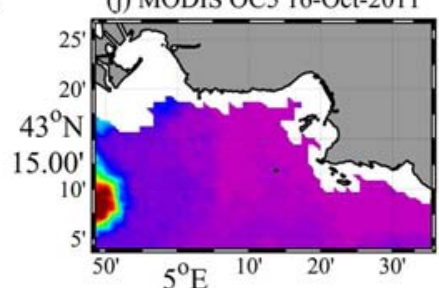

(k) Nutrient limitation on 12 Oct 2011

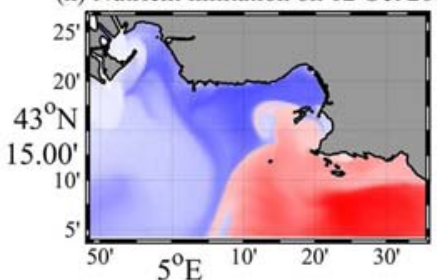

(1) Nutrient limitation on 13 Oct 2011

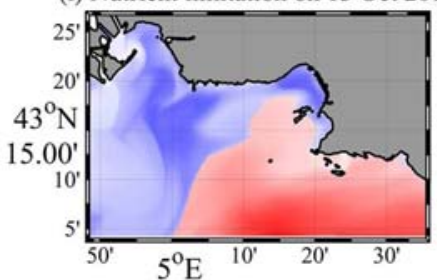

(m) Nutrient limitation on 14 Oct 2011

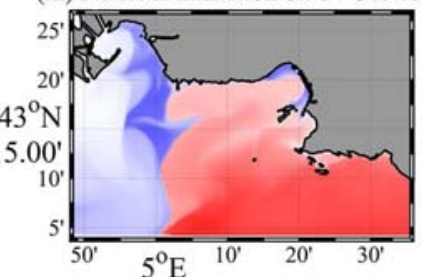

(n) Nutrient limitation on 15 Oct 2011

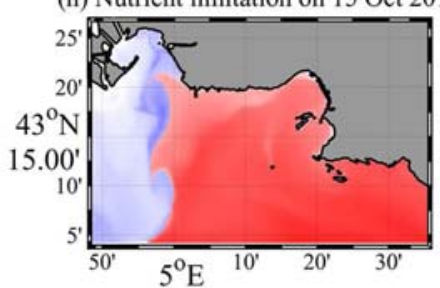

(o) Nutrient limitation on 16 Oct 2011

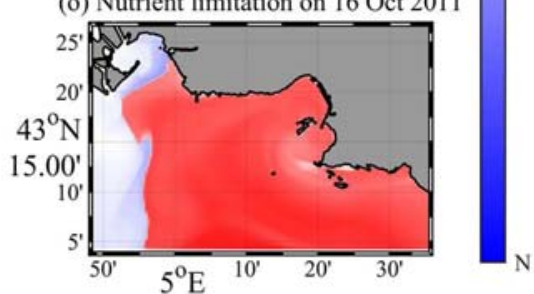

Figure 4: (a) In situ observations of surface Chl-a (filled circles, various times of the day) superimposed on the modelled surface Chl-a concentrations (at 12:00h) for 12 Oct 2011. (b) MODIS image for the same date. Corresponding images for (cd) 13 Oct 2011, (e-f) 14 Oct 2011, (g-h) 15 Oct 2011 and (i-j) 16 Oct 2011. The color scale on the left is valid for panels (a) through (j) and is in $\mathrm{mg} \mathrm{m}^{-3}$. Panels ( $\mathrm{k}$ ) to (o) have their own color scale on the right and show the modelled nutrient limitation in the surface layer for the same dates as before. Red colors signify that photosynthesis is phosphorous limited, blue colors indicate limitation by nitrogen and white colors suggest little or no limitation. The color intensity corresponds to the strength of the limitation. 
216 continued and the Marseille Eddy was fully developed, extending to depths of about 50m

217 (Figure $3 \mathrm{~g}$ ). The SST on the shelf is now fairly homogeneous and close to $20^{\circ} \mathrm{C}$.

This particular intrusion event of the NC had been directly preceded by an episode of

219

220

221

strong north-westerly Mistral winds which had induced an upwelling near the coast which in turn led to an increase in local surface Chl- $a$ concentrations to values of between 0.5 to 0.6 $\mathrm{mg} \mathrm{m}^{-3}$ in the upwelling zone (Figure 4a, b). On 13 October 2011, this upwelling event was still in progress (cf. temperature distribution in Figure 3a-b) and both model simulations and satellite images show high Chl- $a$ concentrations near the coast (Figure 4c, d). Due to the inherent difficulties for the remote sensing algorithms near the coast [Antoine et al., 2008], we have no satellite estimates in the most shallow areas but given its error margin of about $30 \%$ [Volpe et al., 2012], the remote sensing data is in good agreement with the in situ observations as well as the model hindcasts. As the intrusion event progresses in time and space, surface Chl- $a$ concentrations gradually drop to values of about $0.1 \mathrm{mg} \mathrm{m}^{-3}$ throughout the eastern Gulf (Figure 4e-j). This is also visible in the satellite images where the Chl- $a$ concentrations drop to near the OC5 algorithm's detection limit of $0.1 \mathrm{mg} \mathrm{m}^{-3}$ on 16 October 2011 (Figure 4j).

In the model, phytoplankton primary production is controlled by the most limiting internal nutrient ratio, i.e., either the intracellular N:C or P:C ratio (cf. Eq. 4 in Fraysse et al. [2013]). Commensurate with simulation results of an upwelling event that took place in 2008 (cf. Fig 9b in Fraysse et al. [2013]), we found that the rates of phytoplankton photosynthesis tend to be nitrogen rather than phosphorous limited in the upwelling zone (Figure 4k). In fact, the model domain is clearly divided into an $\mathrm{N}$ limited coastal (upwelling) area and a P limited region which corresponds to the Northern Current. The Rhone River plume to the west is nutrient replete and only light limited which can be seen from the almost white colour in that area which indicates that the cellular nutrient-to-carbon ration is high, both for $\mathrm{N}: \mathrm{C}$ and $\mathrm{P}: \mathrm{C}$. 
NO3

$$
0.12
$$

0.28

0.06

0.13

NH4

0.93

0.80

0.32

0.27

PO4

0.11

0.12

0.06

0.02

241 As the NC intrusion progresses, the model suggests an increasing phosphorous limitation on

242 the shelf (Figure 41 through o). On 18 October (not shown) photosynthesis rates over the

243 entire domain (apart from the Rhone River plume) are P limited (commensurate with the

244 extent of the $\sim 20^{\circ} \mathrm{C}$ isothermal on the SST image in Figure $3 \mathrm{~h}$ ). The fact that the intrusion of

245 warmer NC water also led to the intrusion of oligotrophic water onto the shelf was confirmed

246 by the analyses of in situ water samples. While pre-intrusion (12 Oct 2011) phosphate levels

247 in the surface layer could locally reach values of the order of $0.1 \mu \mathrm{M}$ (Table 1), the

248 concentrations dropped to very low values once the intrusion was in full swing (16/17 Oct

249 2011) (Table 1 and 2). For nitrate and ammonium, the surface layer was also completely

250 depleted by 16 October 2011 although there was some ammonium present at depth which may be linked to the sizable Chl- $a$ concentration there (Table 2).

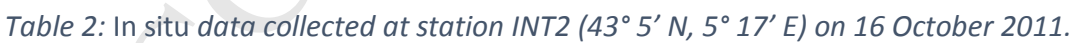

\begin{tabular}{ccccc}
\hline Depth $(\mathrm{m})$ & Chl- $a\left(\mathrm{mg} \mathrm{m}^{-3}\right)$ & $\mathrm{NH}_{4}(\mu \mathrm{M})$ & $\mathrm{NO}_{3}(\mu \mathrm{M})$ & $\mathrm{PO}_{4}(\mu \mathrm{M})$ \\
\hline 0 & 0.11 & no data & 0.02 & 0.06 \\
15 & 0.13 & 0.28 & 0.00 & 0.02 \\
40 & 0.22 & 0.22 & 0.00 & 0.01 \\
60 & 0.26 & 0.20 & 0.00 & 0.01 \\
80 & 0.32 & 0.42 & 0.05 & 0.02 \\
100 & 0.14 & no data & 0.04 & 0.12
\end{tabular}


253 on the shelf (Figure 5). By 16 October the intrusion has replaced the cooler shelf water,

254 which had been upwelled prior to 13 October, with warm water from the NC (Figure 5a, b).

255 At the same time, the deep chlorophyll maxim that was present on 13 October has also been
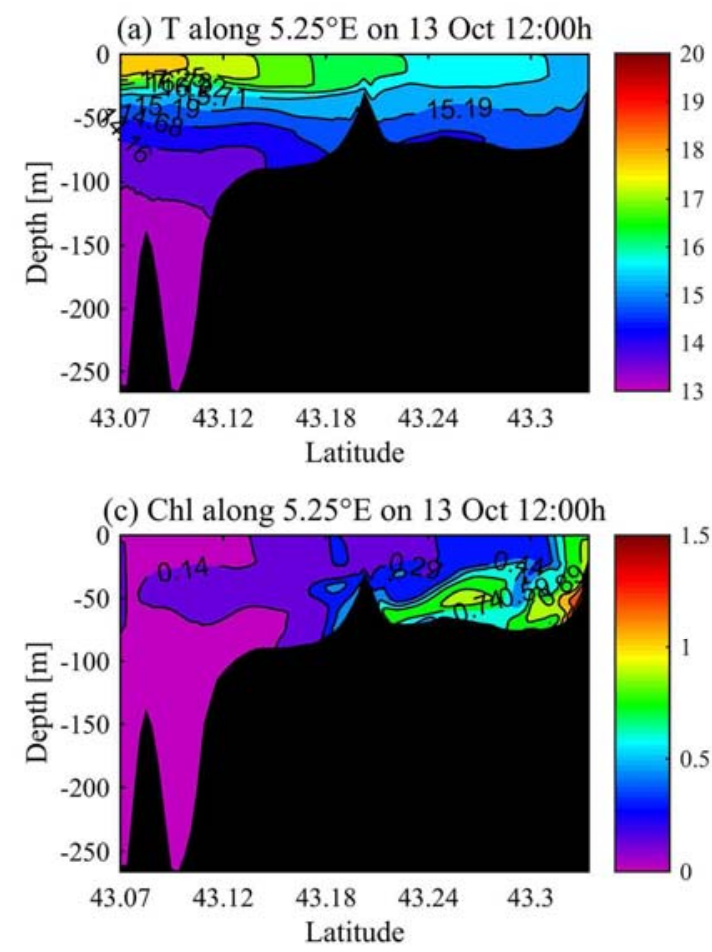

(e) $\mathrm{NO}_{3}$ along $5.25^{\circ} \mathrm{E}$ on 13 Oct $12: 00 \mathrm{~h}$

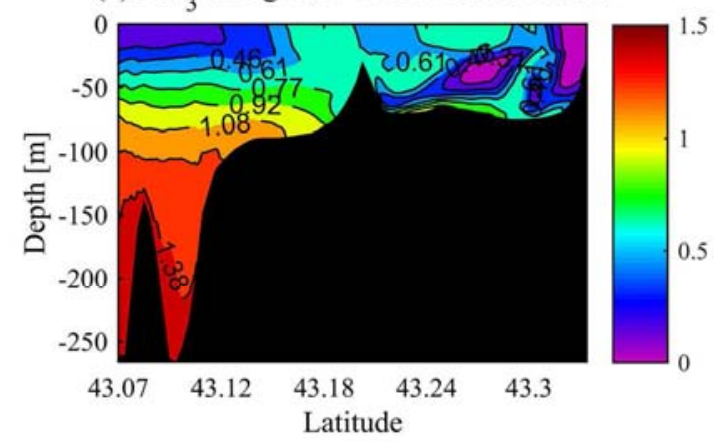

(g) $\mathrm{PO}_{4}$ along $5.25^{\circ} \mathrm{E}$ on $13 \mathrm{Oct} 12: 00 \mathrm{~h}$

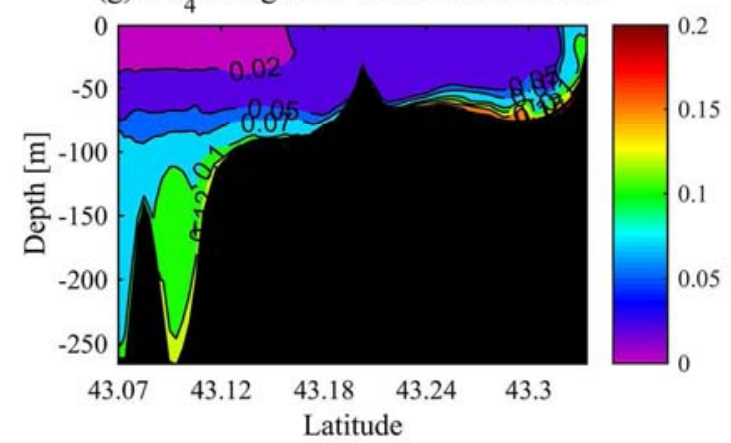

(b) $\mathrm{T}$ along $5.25^{\circ} \mathrm{E}$ on 16 Oct $12: 00 \mathrm{~h}$
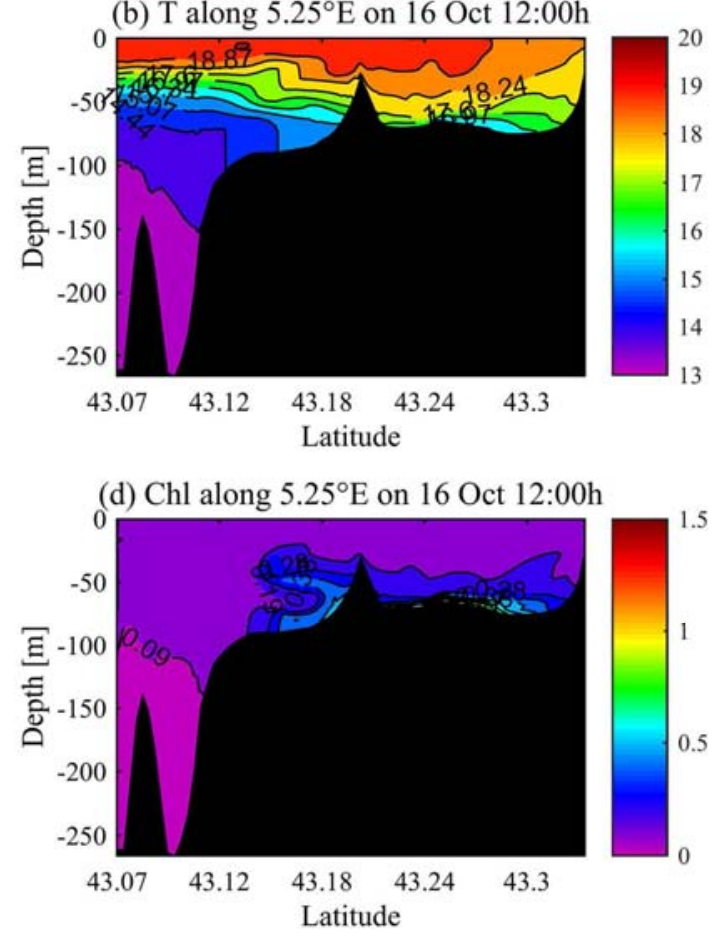

(f) $\mathrm{NO}_{3}$ along $5.25^{\circ} \mathrm{E}$ on 16 Oct $12: 00 \mathrm{~h}$

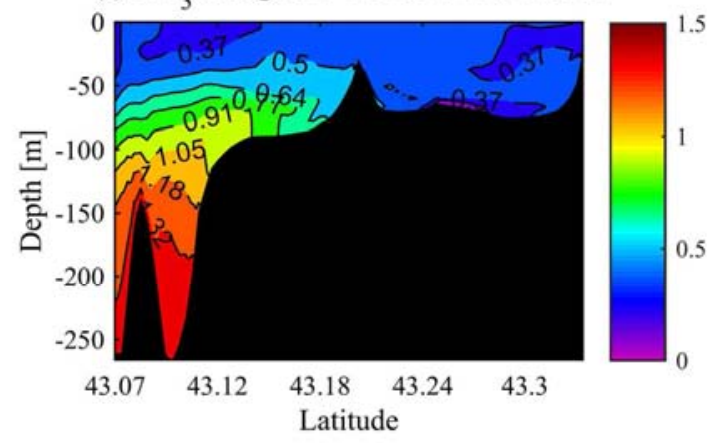

(h) $\mathrm{PO}_{4}$ along $5.25^{\circ} \mathrm{E}$ on 16 Oct $12: 00 \mathrm{~h}$

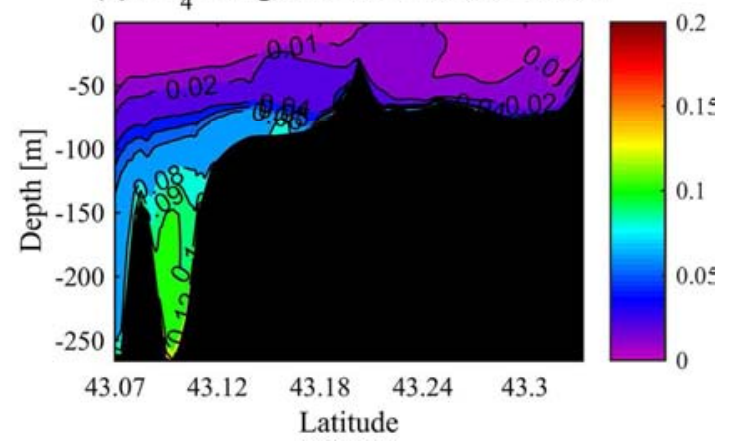

Figure 5: Vertical sections along $5^{\circ} 15^{\prime} \mathrm{E}$ on 13 Oct (post-upwelling/pre-intrusion) and 16 Oct (mid intrusion) showing $(a, b)$ water temperature in ${ }^{\circ} \mathrm{C} ;(c, d)$ chl-a concentration in $\mathrm{mg} \mathrm{m}^{-3}$; $(e, f) \mathrm{NO}_{3}$ concentration in $\mathrm{mmol}^{-1}$; and $(g, h) \mathrm{PO}_{4}$ concentration in $\mathrm{mmol}^{-1}$. 
$257 \mathrm{NO}_{3}$ is very low in the areas affected by the upwelling along the coast (Figure 5e) while $\mathrm{PO}_{4}$

258 is increased at the same time (Figure 5g). Three days later, $\mathrm{NO}_{3}$ concentrations have

259 increased near the coast (to about $0.34 \mathrm{mmol} \mathrm{L}^{-1}$, Figure $5 \mathrm{f}$ ) while $\mathrm{PO}_{4}$ concentration have

260 dropped to less than $0.01 \mathrm{mmol} \mathrm{L}^{-1}$ in the surface layer (Figure $5 \mathrm{~h}$ ).

262 intrusion event, we calculated the changes in the mass budgets [see equations 3 and 4 in

263 Fraysse et al., 2014] for some of the model variables. For this purpose we focus on a coastal

264 sub-zone (Figure 1b), which contains most of the larger upwelling areas but excludes the

265 Rhone delta which lies a few kilometres to the west and also the normal path of the NC

266 further offshore. The results (Figure 6) show an increase in the biological production of

267 carbon associated with increases due to advective processes of the two main nutrients, $\mathrm{N}$ and

268 P, during the upwelling period from 7 till the 13 October 2011. Most of the new production

$269\left(\mathrm{~B}^{\mathrm{BIO}}\right.$ in Figure 6) is exported almost immediately (via $\mathrm{B}^{\mathrm{OB}}$ ), which leaves the total budget

$270\left(\mathrm{~B}^{\mathrm{TOT}}\right)$ unchanged, or even slightly negative due to the losses through the open boundaries.

observed a significant change in the mass budgets. The new production of carbon levels off,
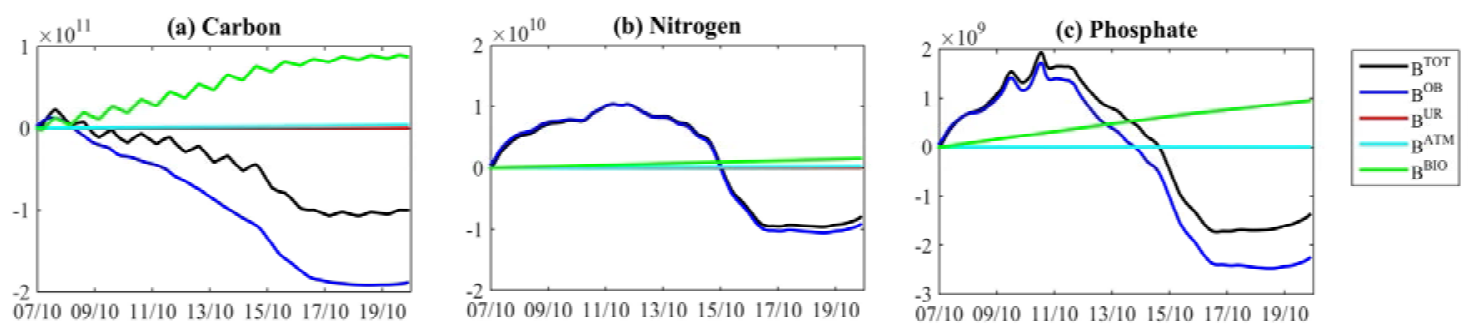

Figure 6: Mass budgets for (a) total carbon, (b) total nitrogen and (c) total phosphorous for the coastal zone box shown in Error! Reference source not found.b and the period covering the upwelling (7-13 October) and subsequent intrusion of the Northern Current. The curves show cumulative changes in total mass (depth integrated) relative to 7 October 2011; hence absolute values are not representative of the instantaneous state of the system but show the accumulated change relative to day 0 , while the gradients give an indication of instantaneous changes (fluxes). The curves represent changes in the total mass budget (TOT) due to losses/gains through the open boundaries (OB), input by urban rivers (UR) and atmospheric deposition (ATM), as well as changes due to biological processes (BIO). 
276 same trends can be observed for the two main nutrients which exhibit a sharp decline in their

277 standing stock.

278

\section{Discussion}

We examined an intrusion event of the Northern Current onto the continental shelf in the eastern Gulf of Lion (NW Mediterranean). Such intrusions had been observed [Petrenko et al., 2005; Petrenko et al., 2013] but their impact on the local biogeochemistry had not been studied until now.

The intrusion event that took place between 13 to 18 October 2011 was preceded by several days of strong (> $15 \mathrm{~m} \mathrm{~s}^{-1}$ ) north- to north-westerly winds (Mistral) which ceased on 14 October with the wind direction turning to easterly (Figure 2). The sustained Mistral had led to upwelling events along the coast of the Bay of Marseille with the introduction of cooler phosphorous-rich water into the surface layer (Figure $3 \mathrm{a}, \mathrm{b}$ ) and associated increases in Chl- $a$ used as a proxy for phytoplankton primary production (Figure 4a-d).

We could clearly identify the intrusion event based on the modelled and measured velocity fields which exhibited a clear and sustained on-shelf velocity component at the eastern entrance to the Gulf (Figure 3). Within a time frame of 2 to 3 days, the intrusion event led to a marked change in the temperature structure on the shelf, replacing the previously upwelled nutrient-rich cool water with warmer oligotrophic water from the Northern Current. The effect was so dramatic that within only 2-3 days the entire region had its surface temperature increased by about $4{ }^{\circ} \mathrm{C}$ (Figure 3$)$ and the average Chl- $a$ concentration reduced by about 0.3-0.4 $\mathrm{mg} \mathrm{m}^{-3}$ (Figure 4). In good agreement with previous studies [Petrenko et al., 2005; Petrenko et al., 2013], we found that the intrusion had an impact over the entire water column with discernible on-shore velocity components and effects on ambient nutrient concentration being observed down to a depth of about $80 \mathrm{~m}$ (cf. Figure 5). 
301 the eastern GoL to be of the order of about $0.5 \mathrm{~Sv}$ [Petrenko et al., 2005] and $0.37 \mathrm{~Sv}$

302

303

304

305

306

307

308

309

310

311

[Petrenko et al., 2013] respectively. We calculated that for each day that such a flux persists, it would replace about $20-25 \%$ of the on-shelf water north of $43.1^{\circ} \mathrm{N}$ and east of $4.6^{\circ} \mathrm{E}$.

Considering the speed with which the temperature and Chl- $a$ structure on the shelf changed

(cf. Figure 3 and 5), we could hypothesize that the on-shelf fluxes during the October 2011 intrusion may have been of the same order of magnitude or maybe even slightly higher, although neither SST nor Chl- $a$ alone are sufficiently reliable indicators. Using the modelled zonal velocities, we calculated an average on-shelf (northward) flux of about $0.45 \mathrm{~Sv}$ across a line at $43.07^{\circ} \mathrm{N}$ between 15 and 18 October 2011 with short-term peak values reaching about $0.65 \mathrm{~Sv}$. However, considering that the model tends to slightly overestimate the velocities measured by the ADCP (cf. Figure 3f), these values may only be slightly too high.

It is difficult to generalize the effect that such an intrusion would have on the biogeochemistry because its impact strongly depends upon the state of the ecosystem at the time the intrusion occurs. During the already oligotrophic summer months, for instance, intrusions of oligotrophic $\mathrm{NC}$ water would have a much more subdued effect compared to an intrusion that was to occur during a bloom period. Blooms in the eastern GoL can be of a seasonal nature, or be caused by short-lived events such as Mistral-induced upwellings or Rhone River intrusions advecting nutrient-rich Rhone water from the west [Fraysse et al., 2014]. For our particular study period in October 2011, the impact was significant as the region had been experiencing a sustained period of Mistral and associated upwelling immediately prior to the intrusion which led to the presence of relatively nutrient rich waters and an increase in local primary production. The intrusion that began on 13 October 2011 put a sudden stop to this mini-bloom. Chl- $a$ concentrations of previously over $0.5 \mathrm{mg} \mathrm{m}^{-3}$ dropped to values of less than $0.2 \mathrm{mg} \mathrm{m}^{-3}$ throughout the eastern Gulf within a matter of 2 to 3 days (Figure $3 a$ through $\mathrm{j}$ ). Also the nutrient concentrations decreased significantly and the 
327 remaining at depth (Table 1).

328 Typically, this part of the Mediterranean is phosphorous limited [Pujo-Pay et al.,

329

330

331

332

2006]. Commensurate with previous findings [Fraysse et al., 2013], the upwelling seemed to decrease the dissolved $\mathrm{NO}_{3}: \mathrm{PO}_{4}$ ratio, thereby turning the typical phosphorous into a upwelling-induced nitrogen limitation (Figure $4 \mathrm{k}, 5 \mathrm{e}$ and $\mathrm{f}$ ). The near-shore surface $\mathrm{NO}_{3}: \mathrm{PO}_{4}$ ratio on 13 October, i.e. immediately after the upwelling and prior to the intrusion was 2:1 (Figure 5e-h), indicating a severe nitrogen limitation. Once the oligotrophic water from the Northern Current started to move onshore, the previously upwelled waters were replaced and the model showed a marked shift from N- back to P-limitation in phytoplankton photosynthesis (with NO3:PO4 ratios reaching 40:1 in the surface waters, Figure 41 through o, Figure 5 e-h). The intrusion thus rendered the entire eastern Gulf phosphorous limited with Chl- $a$ concentrations near the OC5 algorithm's detection limit and $\mathrm{PO}_{4}$ concentrations in the surface layer dropping to below $0.01 \mathrm{mmol} \mathrm{L}^{-1}$ (Figure $5 \mathrm{~g}-\mathrm{h}$ ). As there are no in situ nutrient data to cover the entire temporal succession from pre-upwelling, over upwelling to intrusion, these last results should be regarded as preliminary only until they can be either verified or disproven by in situ observations. This would require a dedicated field campaign with daily measurements possibly lasting 10-14 days to monitor the entire series of events.

In a study in the north-western Gulf of Mexico, Chen et al. [2000] also observed a drop in primary production between 2 successive years which they attributed to the intrusion of oligotrophic offshore water. The difference in Chl concentration was less dramatic, however, and given the one year time difference between observations, results are not easily comparable.

In the Yangtze River Delta, Jiao et al. [2007] also observed an intrusion of warmer offshore water from the Kuroshio current, replacing Yangtze plume water and leading to a change in phytoplankton abundance. In contrast to the NC, the Kuroshio is a nutrient-rich 
353 primary production, mainly due to the higher visibility and thus better light penetration in the

354 Kuroshio water compared to the more turbid Yangtze plume water.

Studies that examined the intrusion of the oligotrophic subtropical extension of the

356 East-Australian current onto the NW New Zealand shelf found a similar impact for the on-

357 shelf primary production [Sharples, 1997; Zeldis, 2004; Zeldis et al., 2004]. Due to the

358 nitrogen limitation in the intruding waters, chlorophyll concentrations had dropped

359 dramatically in the surface layer. However, in that particular case, the intrusion was limited to

360 a shallow surface layer, which allowed phytoplankton to bloom at depth, i.e., at the interface

361 between the clear surface waters and the nutrient rich bottom layer. Another striking effect

that was caused by that intrusion was the introduction of offshore fish species and toxic phytoplankton species onto the shelf.

All these studies compared the effect of intrusions based on observations that were sometimes as far apart as 1 year [Chen et al., 2000]. In contrast, the present work examined for the first time to our knowledge - the actual dynamics of such intrusion events and could demonstrate how abrupt and significant these changes can be. Unfortunately, research on NC intrusions in the GoL is a rather recent field of research and much is still to be discovered about the response of and the possible impact on the wider ecosystem and higher trophic levels, including fisheries. From a management perspective, it would be important to know how these intrusions affect secondary producers. Changes in the discharge volume of the Rhone River into the GoL have been found to directly impact on the amount of landings of Common Sole (Solea solea) 5 years later (M. Harmelin, pers. comm.). It would seem like a plausible assumption that any possible impact due to changes in the frequency and/or magnitude of intrusions would also take about 5 years to penetrate to the upper levels of the food web. This is particularly relevant, considering that the GOL is the most productive and profitable region for fisheries in the Western Mediterranean and about $50 \%$ of the catch in the 
379 described in this study. However, no long term data on intrusions is available. It is only

380 recently, that people have begun to look at the frequency and magnitude of NC intrusions.

Findings, in particular by Gatti et al. [Intrusions of the Mediterranean Northern Current on

the eastern side of the Gulf of Lion's continental shelf: characterization and generating processes, submitted to Journal of Geophysical Research 2014] and Barrier et al. [2015], suggest that these intrusions are not only frequent but also rather large in terms of horizontal fluxes, and thus capable of inducing frequent and significant changes to the GOL ecosystem. Further observations and modelling efforts are urgently needed in order to fully describe these processes and their impact on the ecosystem in more detail.

\section{Acknowledgements}

The authors wish to acknowledge the Compagnie Nationale du Rhone for the Rhone

River discharge data, as well as Meteo France for meteorological data. The mooring and satellite SST data were collected and made freely available by the MyOcean project and the programs that contribute to it. The authors thank the GFSC, Greenbelt, MD 20771, for the production and distribution of MODIS ocean color data, processed by IFREMER. The Rhone concentration data were provided by the National MOOSE Program and the Service d'Observation of the Mediterranean Institute of Oceanography (MIO), and the vessel mounted ADCP data by the technical staff of INSU in the framework of the SAVED platform. We also acknowledge B. Queguiner and D. Malengros for allowing the ADCP transects during the SPECIMED cruises, and all the technical staff involved in the RHOMA2011 IFREMER cruise. The authors acknowledge the staff of the "Cluster de calcul intensif HPC" Platform of the OSU Institut Pythéas (Aix-Marseille University, INSU-CNRS)

402 for providing the computing facilities as well as M. Libes and C. Yohia for technical 
(AERMC) and MASSILIA (PNEC-EC2CO) projects. Additional support came from the

405

406

407

408

409

410

411

412

413

414

415

416

417

418

419

420

421

422

423

424

425

426

427

428

429

430

431

432

433

434

435

436

437

MERMEX (WP3-C3A-Mistrals), IMBER and LOICZ as well as the European PERSEUS

projects (EC grant agreement 287600). ONR wishes to acknowledge financial support from

the People Programme (Marie Curie Actions) of the European Union's Seventh Framework

Programme FP7/2007-2013/ under REA grant agreement ${ }^{\circ} 624170$ as well as the AMICO-

BIO project (12-MCGOT-GMES-1-CVS-047/MEDDE/CNRS-INSU). We also thank A.

Petrenko, F. Diaz, M. Harmelin, and two anonymous reviewers for their helpful comments on the manuscript.

\section{References}

Alberola, C., and C. Millot (2003), Circulation in the French mediterranean coastal zone near Marseilles: the influence of wind and the Northern Current, Continental Shelf Research, 23(6), 587-610.

Alberola, C., C. Millot, and J. Font (1995), On the Seasonal and Mesoscale Variabilities of the Northern Current during the Primo-O Experiment in the Western MediterraneanSea, Oceanologica Acta, 18(2), 163-192.

Andre, G., P. Garreau, and P. Fraunie (2009), Mesoscale slope current variability in the Gulf of Lions. Interpretation of in-situ measurements using a three-dimensional model, Continental Shelf Research, 29(2), 407-423.

Antoine, D., F. d'Ortenzio, S. B. Hooker, G. Becu, B. Gentili, D. Tailliez, and A. J. Scott (2008), Assessment of uncertainty in the ocean reflectance determined by three satellite ocean color sensors (MERIS, SeaWiFS and MODIS-A) at an offshore site in the Mediterranean Sea (BOUSSOLE project), J Geophys Res-Oceans, 113(C7).

Baklouti, M., V. Faure, L. Pawlowski, and A. Sciandra (2006a), Investigation and sensitivity analysis of a mechanistic phytoplankton model implemented in a new modular numerical tool (Eco3M) dedicated to biogeochemical modelling, Progress In Oceanography, 71(1), 34-58.

Baklouti, M., F. Diaz, C. Pinazo, V. Faure, and B. Queguiner (2006b), Investigation of mechanistic formulations depicting phytoplankton dynamics for models of marine pelagic ecosystems and description of a new model, Progress In Oceanography, 71(1), 1-33.

Barrier, N., A. A. Petrenko, and Y. Ourmières (2015), Strong intrusions of the Northern Mediterranean Current on the eastern Gulf of Lion: insights from in-situ observations and high resolution numerical modelling, Ocean Dynamics, accepted. 
Chen, X., S. E. Lohrenz, and D. A.Wiesenburg (2000), Distribution and controlling mechanisms of primary production on the Louisiana-Texas continental shelf, Journal of Marine Systems, 25(2), 179-207.

Coste, B. (1974), Role des apports nutritifs mineraux rhodaniens sur la production organique des eaux du Golfe du Lion, Tethys, 6, 727-740.

de Madron, X. D., et al. (2011), Marine ecosystems' responses to climatic and anthropogenic forcings in the Mediterranean (vol 91, pg 97, 2011), Progress in Oceanography, 91(4), 593-594.

Echevin, V., M. Crepon, and L. Mortier (2003), Interaction of a coastal current with a gulf: Application to the shelf circulation of the Gulf of Lions in the Mediterranean Sea, Journal of Physical Oceanography, 33(1), 188-206.

El Sayed, M. A., A. Aminot, and R. Kerouel (1994), Nutrients and Trace-Metals in the Northwestern Mediterranean under Coastal Upwelling Conditions, Continental Shelf Research, 14(5), 507-530.

Estournel, C., X. D. de Madron, P. Marsaleix, F. Auclair, C. Julliand, and R. Vehil (2003), Observation and modeling of the winter coastal oceanic circulation in the Gulf of Lion under wind conditions influenced by the continental orography (FETCH experiment), J Geophys Res-Oceans, 108(C3).

Faure, V., C. Pinazo, J. P. Torreton, and P. Douillet (2010a), Modelling the spatial and temporal variability of the SW lagoon of New Caledonia II: Realistic 3D simulations compared with in situ data, Mar Pollut Bull, 61(7-12), 480-502.

Faure, V., C. Pinazo, J. P. Torreton, and S. Jacquet (2010b), Modelling the spatial and temporal variability of the SW lagoon of New Caledonia I: A new biogeochemical model based on microbial loop recycling, Mar Pollut Bull, 61(7-12), 465-479.

Fraysse, M. (2014), Rôle du forçage physique sur l'écosystème à l'est du Golfe du Lion: modulation de l'impact des apports anthropiques en sels nutritifs et matrière organique étudiée par modelisation 3D couplée physique et biogéochimique, $\mathrm{PhD}$ thesis, $338 \mathrm{pp}$, Aix-Marseille University, Marseille, France.

Fraysse, M., I. Pairaud, O. N. Ross, V. M. Faure, and C. Pinazo (2014), Intrusion of Rhone River diluted water into the Bay of Marseille: Generation processes and impacts on ecosystem functioning, J Geophys Res-Oceans, 119.

Fraysse, M., C. Pinazo, V. M. Faure, R. Fuchs, P. Lazzari, P. Raimbault, and I. Pairaud (2013), Development of a 3D Coupled Physical-Biogeochemical Model for the Marseille Coastal Area (NW Mediterranean Sea): What Complexity Is Required in the Coastal Zone?, PLOS ONE, 8(12).

Gatti, J., A. Petrenko, J.-L. Devenon, Y. Leredde, and C. Ulses (2006), The Rhone river dilution zone present in the northeastern shelf of the Gulf of Lion in December 2003, Continental Shelf Research, 26(15), 1794-1805.

Gohin, F., S. Loyer, M. Lunven, C. Labry, J. M. Froidefond, D. Delmas, M. Huret, and A. Herbland (2005), Satellite-derived parameters for biological modelling in coastal waters: Illustration over the eastern continental shelf of the Bay of Biscay, Remote Sensing of Environment, 95(1), 29-46.

Jiao, N., et al. (2007), Ecological anomalies in the East China Sea: Impacts of the Three Gorges Dam?, Water Research, 41(6), 1287-1293. 
Lazure, P., and F. Dumas (2008), An external-internal mode coupling for a 3D hydrodynamical model for applications at regional scale (MARS), Adv Water Resour, 31(2), 233-250.

Millot, C. (1990), The Gulf of Lions Hydrodynamics, Continental Shelf Research, 10(9-11), 885-894.

Millot, C. (1999), Circulation in the Western Mediterranean Sea, Journal of Marine Systems, 20(1-4), 423-442.

Millot, C., and L. Wald (1980), The Effect of Mistral Wind on the Ligurian Current near Provence, Oceanologica Acta, 3(4), 399-402.

Morel, A., A. Bricaud, J. M. Andre, and J. Pelaez-Hudlet (1990), Spatial- temporal evolution of the Rhone plume as seen by CZCS imagery. Consequences upon the primary production in the Gulf of Lion., in Water Pollution Research Reports of the European Communities, edited by J. M. Martin and H. Barth, pp. 45-62, NERC, Plymouth, UK.

Pairaud, I. L., J. Gatti, N. Bensoussan, R. Verney, and P. Garreau (2011), Hydrology and circulation in a coastal area off Marseille: Validation of a nested 3D model with observations, Journal of Marine Systems, 88(1), 20-33.

Petrenko, A. (2003), Variability of circulation features in the gulf of lion NW Mediterranean Sea. Importance of inertial currents, Oceanologica Acta, 26(4), 323-338.

Petrenko, A., Y. Leredde, and P. Marsaleix (2005), Circulation in a stratified and wind-forced Gulf of Lions, NW Mediterranean Sea: in situ and modeling data, Continental Shelf Research, 25(1), 7-27.

Petrenko, A., C. Dufau, and C. Estournel (2008), Barotropic eastward currents in the western Gulf of Lion, north-western Mediterranean Sea, during stratified conditions, Journal of Marine Systems, 74(1-2), 406-428.

Petrenko, A., M. Kersale, F. Nencioli, J. Gatti, and I. Dekeyser (2013), Coastal circulation in the Gulf of Lion, the influence of mesoscale processes on interregional exchanges, paper presented at 40th CIESM Congress, Marseille, France.

Pinazo, C., P. Marsaleix, B. Millet, C. Estournel, and R. Vehil (1996), Spatial and temporal variability of phytoplankton biomass in upwelling areas of the northwestern Mediterranean: A coupled physical and biogeochemical modelling approach, Journal of Marine Systems, 7(2-4), 161-191.

Pujo-Pay, M., P. Conan, F. Joux, L. Oriol, J. J. Naudin, and G. Cauwet (2006), Impact of phytoplankton and bacterial production on nutrient and DOM uptake in the Rhone river plume (NW Mediterranean), Marine Ecology Progress Series, 315, 43-54.

Rubio, A., V. Taillandier, and P. Garreau (2009), Reconstruction of the Mediterranean northern current variability and associated cross-shelf transport in the Gulf of Lions from satellite-tracked drifters and model outputs, Journal of Marine Systems, 78, S63S78.

Schaeffer, A., A. Molcard, P. Forget, P. Fraunié, and P. Garreau (2011), Generation mechanisms for mesoscale eddies in the Gulf of Lions: radar observation and modeling, Ocean Dynamics, 61, 1587-1609.

Sempere, R., B. Charriere, F. Van Wambeke, and G. Cauwet (2000), Carbon inputs of the Rhone River to the Mediterranean Sea: Biogeochemical implications, Global Biogeochemical Cycles, 14(2), 669-681. 
Sharples, J. (1997), Cross-shelf intrusion of subtropical water into the coastal zone of northeast New Zealand, Continental Shelf Research, 17(7), 835-857.

528 Volpe, G., S. Colella, V. Forneris, C. Tronconi, and R. Santoleri (2012), The Mediterranean Ocean Colour Observing System - system development and product validation, Ocean Science, 8(5), 869-883.

Zeldis, J. R. (2004), New and remineralised nutrient supply and ecosystem metabolism on the northeastern New Zealand continental shelf, Continental Shelf Research, 24(4-5), 563-581.

Zeldis, J. R., R. A. Walters, M. J. N. Greig, and K. Image (2004), Circulation over the northeastern New Zealand continental slope, shelf and adjacent Hauraki Gulf, during spring and summer, Continental Shelf Research, 24(4-5), 543-561. 